\title{
ANALISIS KECEPATAN KERJA SACO SAAT MANUVER BEBAN DI BANDARA NGURAH RAI MENGGUNAKAN ARTIFICIAL NEURAL NETWORK
}

\author{
Dewa Ngakan Made Barel ${ }^{1}$, I Gede Dyana Arjana ${ }^{2}$, Widyadi Setiawan ${ }^{3}$ \\ Program Studi Teknik Elektro, Fakultas Teknik, Universitas Udayana \\ Email: bareldewa89@gmail.com ${ }^{1}$, dyanaarjana@unud.ac.id ${ }^{2}$, widyadi@unud.ac.id ${ }^{3}$
}

\begin{abstract}
ABSTRAK
Bandara Ngurah Rai memiliki beban daya sebesar 10.380 kVA, disuplai oleh dua penyulang yakni penyulang Gayatri dan peyulang Bandara. Penyulang Gayatri sebagai penyulang utama dan penyulang Bandara sebagai penyulang cadangan. Penggunaan dua penyulang ini bertujuan untuk mengatasi gangguan pada jaringan, dikarenakan sensitifitas peralatan listrik di bandara yang tinggi. Namun apabila terjadi gangguan pada penyulang Gayatri maka suplai beban secara otomatis akan dipindahkan ke penyulang Bandara menggunakan sakelar otomatis bernama Switching Automatic Change Over (SACO). Tingkat sensitifitas peralatan listrik Bandara Ngurah Rai yang tinggi mengijinkan batas jatuh tegangan maksimum adalah $0,5 \mathrm{kV}$ dari nilai tegangan nominal penyulang, dari permasalahan tersebut maka dilakukan analisis perhitungan jatuh tegangan dan hubung singkat pada penyulang Gayatri. Analisis ini menggunakan program Artificial Neural Network (ANN). Parameter yang digunakan antara lain jumlah iterasi yaitu 60000 epoch, kecepatan pembelajaran 0,3 dan hidden layer sebanyak 40 hidden layer, dimana nilai target pengujiannya adalah 0,00001. Proses pelatihan dan pengujian yang telah dilakukan menghasilkan nilai jatuh tegangan pada titik $100 \%$ (ujung penyulang) adalah 274,7 volt dengan nilai Mean Squarred Error (MSE) yaitu 45,5. Nilai waktu tunda rele tercepat yaitu 0,3 detik pada titik gangguan $5 \%$, dan nilai MSE dengan hasil terbaik adalah 0,00032 untuk gangguan 1 fasa ke tanah.
\end{abstract}

Kata Kunci : Waktu tunda rele, SACO, Neural network, MSE

\section{ABSTRACT}

Ngurah Rai Airport has a power load of 10380 kVA, supplied by two feeders namely Gayatri feeder and Bandara feeder, Gayatri feeder is as the primary feeder and Bandara feeder is as backup feeder. The use of these two feeders aims to overcome the interference on the network, due to the fact that the sensitivity of electrical equipments at airports is high. However, if there is an interruption in the supply load of Gayatri feeder then the load supply will automatically be transferred to the Bandara feeder using automatic switch which is called Switching Automatic Change Over (SACO). The high sensitivity level of the electrical equipment of Ngurah Rai allows maximum voltage drop limit of $0.5 \mathrm{kV}$ of feeder nominal voltage value. Relating to the problems, an analysis is made on the voltage drop calculations and short circuit on Gayatri feeder. This analysis uses the program Artificial Neural Network (ANN). Parameters that are used included the number of iterations totaling 60000 epochs, the learning speed of 0.3 and hidden layer of 40 , wherein the target value of the test is 0.00001 . The process of training and testing that has been done to produce a voltage drop value at 100 (end feeder) is a 274.7 volt with the Squared Mean Error (MSE) value of 45.5. Value fastest time delay relay was 0.3 seconds at the point of interruption 5\%, and the MSE with the best result is 0.00032 to 1 phase to ground disturbance.

Keywords : Time delay relay, SACO, Neural Network, MSE

\section{PENDAHULUAN}

Bandara Ngurah Rai disuplai dengan tegangan $20 \mathrm{kV}$ melalui penyulang Gayatri sebagai penyulang utama dan penyulang Bandara sebagai penyulang cadangan, dimana di dalam Bandara Ngurah Rai ini terdapat terminal domestik dan terminal 
internasional, yang masing-masing memiliki daya beban 10,380 kVA.

Sensitifitas dari peralatan-peralatan listrik di Bandara sangat tinggi terhadap gangguan transmisi distribusi listrik, gangguan yang dimaksud di sini adalah gangguan jatuh tegangan dan arus hubung singkat 3 phasa, 2 phasa, dan 1 phasa ke tanah. Saat terjadi gangguan di sepanjang penyulang Gayatri suplai beban otomatis berpindah ke penyulang Bandara yang dalam keadaan stand by, proses perpindahan otomatis ini menggunakan switch Switching Automatic Change Over (SACO) dengan berkoordinasi dengan rele arus yang terpasang. Oleh karena itu, pihak Bandara memberikan syarat batas jatuh tegangan yang diperbolehkan maksimum $0,5 \mathrm{kV}$ dari tegangan nominal, dan waktu tunda kerja 0,3 detik.

Analisis kecepatan kerja SACO dilakukan dengan cara membandingkan hasil perhitungan dari nilai jatuh tegangan pada titik $100 \%$ (ujung) penyulang dan nilai kecepatan waktu tunda kerja rele dengan hasil pengujian dan juga pelatihan menggunakan program Artificial Neural Network (ANN) sehingga didapatkan selisih nilai Mean Squared Error (MSE) dari nilai perhitungan dan hasil pengujian dalam program ANN tersebut.

\section{KAJIAN PUSTAKA}

\subsection{Jatuh Tegangan}

Sistem tenaga listrik dapat dijalankan dengan beberapa tahapan-tahapan yang harus dilalui hingga energi listrik yang dibutuhkan dapat diterima oleh konsumen. Pertama, energi listrik dibangkitkan oleh pembangkit tenaga listrik, yang kemudian disalurkan ke jaringan transmisi Saluran Umum Tegangan Extra Tinggi (SUTET) langsung menuju gardu induk yang kemudian disalurkan ke jaringan distribusi primer Saluran Umum Tegangan Menengah (SUTM) lalu disalurkan lagi ke jaringan distribusi sekunder Saluran Umum Tegangan Rendah (SUTR) yang berfungsi untuk membagikan tenaga listrik kepada beban atau konsumen yang membutuhkan [1].

Permasalahan-permasalahan yang dapat mempengaruhi kualitas daya listrik salah satunya adalah jatuh tegangan, dimana antara tegangan yang dikirim dengan tegangan yang diterima terjadi selisih tegangan [2]
Jaringan distribusi SUTM memiliki jalur pendistribusian yang jauh dan menanggung beban yang selalu dinamis, hal-hal tersebut bisa mengakibatkan terjadi jatuh tegangan [3].

Gambar 1 : Jatuh Tegangan pada Saluran Distribusi (sumber : Roger C. Dugan, 2002)

Gambar 1 metunjukkan bahwa karakteristik listrik pada bagian saluran distribusi merupakan $R$ dan $X$, diumpamakan beban adalah motor yang bersifat reaktif yang mengakibatkan arus nya lagging. Jatuh tegangan yang diperbolehkan pada JTM adalah $2 \%$ dari tegangan kerja untuk sistem spindle dan $5 \%$ dari tegangan kerja yaitu untuk sistem radial di atas tanah dan sistem simpul tergantung kepadatan beban [4]. Nilai jatuh tegangan dapat dihitung dengan mengetahui nilai impedansi dari penghantar yang digunakan, Persamaan (1) digunakan untuk menghitung nilai impedansi penghantar suatu jaringan adalah :

$$
Z=(R+j X) L
$$

Persamaan (2) digunakan untuk menghitung nilai jatuh tegangan.

$$
\Delta V=I(R \cos \theta+X \sin \theta)
$$

Keterangan :

$$
\begin{aligned}
& L \text { adalah panjang penghantar }(\mathrm{km}) \\
& I \text { adalah beban maksimum }(\mathrm{A}) \\
& R \text { adalah tahanan saluran }(\Omega / \mathrm{km}) \\
& X \text { adalah reaktansi saluran }(\Omega / \mathrm{km}) \\
& \theta \text { adalah sudut power factor. }
\end{aligned}
$$

\subsection{Arus Hubung Singkat}

Arus hubung singkat dapat diakibatkan oleh gangguan dari luar maupun dari dalam jaringan. Jenis-jenis gangguan hubung singkat berdasarkan kesimetrisan yaitu gangguan simetris dan asimetris. Gangguan simetris menyebabkan arus dari tegangan pada masing-masing phasa sama, sedangkan gangguan jenis asimetris menyebab-kan arus yang mengalir pada tiap phasa tidak seimbang. Sebelum 
menghitung nilai gangguan hubung singkat diperlukan nilai impedansi sumber, impedansi trafo dan impedansi ekivalen yang dapat dihitung dengan menggunakan Persamaan (3).

$$
M V A_{h s}=I_{h s 3 \theta \max }\left(\text { teg }_{\text {primer }} \text { trafo } x \sqrt{3}\right)
$$

Perhitungan impedansi sumber sis sekunder $(20 \mathrm{kV})$ dapat dihitung setelah menentukan nilai impedansi sumber pada sisi primer $(150 \mathrm{kV})$ dengan menggunakan Persamaan (4).

$$
\begin{gathered}
X s_{(150 k V)}=\frac{k V^{2}}{M V A_{h s}} \\
X s_{(20 k V)}=\frac{k V(\text { sekunder trafo })^{2}}{k V(\text { primer trafo })^{2}} \times X s_{(150 k V)}
\end{gathered}
$$

Perhitungan impedansi trafo hanya diambil nilai reaktansi saja, sedangkan untuk nilai tahanan diabaikan karena nilai yang kecil. Nilai impedansi dasar $Z_{b}$ trafo dalam satuan ohm pada sisi $20 \mathrm{kV}$ dapat dihitung dengan Persamaan (6).

$$
Z_{b}=\frac{k V(\text { sekunder trafo })^{2}}{M V A_{\text {trafo }}}
$$

Nilai impedansi (reaktansi) trafo urutan positif dan negatif dapat dihitung menggunakan Persamaan (7).

$$
X t_{1}=X t_{2}=X t_{(\text {pada 100\%) }} x X t_{(\text {sisi20kV })}
$$

Setelah menentukan nilai impedansi sumber dan impedansi trafo barulah kemudian dihitung impedansi ekivalen dari penghantar. Persamaan (8) digunakan untuk menghitung impedansi ekivalen urutan positif dan negatif.

$$
\begin{aligned}
Z_{1 e k i} & =Z_{2 e k i} \\
& =X s_{(\text {sisi20kV) }}+X t_{1}+Z_{1 \text { penyulang }}
\end{aligned}
$$

Nilai impedansi ekivalen urutan nol dihitung menggunakan Persamaan (9).

$$
Z_{0 e k i}=X t_{0}+3 R N+Z_{0 \text { penyulang }}
$$

Persamaan (10)-(12) digunakan untuk menghitung nilai gangguan hubung singkat 3 phasa, 2 phasa, dan 1 phasa ke tanah secara umum pada suatu penghantar.

$$
\begin{gathered}
I_{3 f}=\frac{V_{p h}}{Z_{1 e k i}} \\
I_{2 f}=\frac{V_{p h}-p h}{Z_{1 e k i}+Z_{2 e k i}} \\
I_{1 f}=\frac{3 \times V_{p h}}{\left(Z_{1 e k i}-Z_{2 e k i}+Z_{0 e k i}\right.}
\end{gathered}
$$

\subsection{Time Multiple Setting (TMS)}

Arus setting untuk rele arus lebih, baik dari sisi primer maupun sekunder trafo tenaga dapat dihitung menggunakan Persamaan (13).

$$
I_{\text {set(primer })}=1,05 \times I_{\text {nominal trafo }}
$$

Nilai TMS dapat dicari dengan mengetahui jenis rele yang digunakan, Persamaan (14) digunakan untuk mencari nilai TMS rele dengan kategori standard invers.

$$
T M S_{(S I)}=\frac{0,14 \times t}{\left(\frac{I_{f}}{I_{S}}\right)^{0,02}-1}
$$

\subsection{Semi Automatic Change Over (SACO) \\ Semi Automatic Change Over} merupakan sebuah switch yang memiliki dua cell khusus yang masing-masing mendapat sumber tegangan, pada posisi normal, cell pasokan utama berada pada posisi tertutup (mensuplai beban), dan cell pasokan cadadangan dalam posisi terbuka (standby). Jika pasokan utama terganggu, maka cell pasokan utama akan terbuka atau putus dan pasokan cadangan akan tertutup dan mensuplai beban [5].

SACO berkoordinasi dengan rele yang terpasang pada sistem proteksi penyulang yang dipasang. Penormalan kembali pasokan listrik dari penyulang cadangan ke penyulang utama dilakukan secara manual, hal ini disebabkan karena pada saat pengalihan terjadi kedip yang dirasakan oleh beban. Manfaat diterapkan SACO adalah untuk mengalihkan pasokan listrik dari penyulang utama ke penyulang cadangan secara otomatis tanpa perlu menunggu ekesekusi dari operator ataupun petugas di lapangan, sehingga dapat menghilangkan waktu padam dan meningkatkan pelayanan penyaluran listrik ke konsumen. 


\subsection{Pemodelan ANN}

Jaringan syaraf tiruan merupakan sejumlah besar processor yang terdistribusi secara parallel dan terdiri dari unit proses yang sederhana, dimana masing-masing unit memiliki kecenderungan untuk menyimpan pengetahuan yang dialami dan dapat digunakan kembali [6].

Ide mendasar dari Artificial Neural Network (ANN) adalah mengadopsi mekanisme berpikir sebuah sistem atau aplikasi yang menyerupai otak manusia, baik untuk proses berbagai sinyal elemen yang diterima, toleransi terhadap kesalahan atau error, dan parallel processing [7]. Seperti otak manusia, jaringan syaraf tiruan terdiri dari beberapa neuron yang saling berhubungan. Informasi yang diterima neuron akan ditransformasikan melalui jaringan keluaran ke neuron yang lain, hubungan ini dikenal dengan bobot [8]

Gambar 2. Struktur Ideal Neural Network (sumber : Sri Kusumadewi, 2004)

Dalam ANN ditentukan nilai selisih dari data asli dengan hasil data dari proses pelatihan dan pengujian yang disebut Mean Squared Error (MSE). Nilai MSE ini berfungsi untuk mengetahui seberapa besar nilai error yang dihasilkan dari proses pelatihan dan pengujian, Persamaan (15) digunakan untuk menghitung nilai MSE.

$$
M S E=\Sigma \frac{E t^{2}}{n}
$$

\section{METODE PENELITIAN}

\subsection{Tahapan Penelitian}

Analisis dalam penelitian ini dilakukan dalam beberapa tahapan sebagai berikut.

a. Pengumpulan dan analisis data beban dan spesifikasi penghantar penyulang Gayatri.

b. Melakukan perhitungan total jatuh tegangan dan waktu tunda rele untuk gangguan jatuh tegangan pada penyulang Gayatri. c. Pengolahan data yang telah didapat dalam program Artificial Neural Network.

Menampilkan hasil dari keluaran Artificial Neural Network berupa nilai optimal jatuh tegangan dan nilai waktu tunda kerja rele pada penyulang Gayatri.

\section{HASIL DAN PEMBAHASAN}

\subsection{Struktur ANN}

Struktur ANN ini terdiri dari 4 input dan 4 output, struktur ANN dapat dilihat pada gambar 3 berikut.
Gambar 3. Struktur Neural Network

\subsection{Impedansi $Z_{1}, Z_{2}$, dan $Z_{0}$ pada} Penyulang Gayatri

Penyulang Gayatri memiliki panjang $7,2 \mathrm{~km}$. Jenis penghantar yang digunakan pada penyulang Gayatri.

Tabel 1. Data Penghantar

\begin{tabular}{|c|c|c|c|c|}
\hline $\begin{array}{c}\text { Jenis } \\
\text { Penghantar }\end{array}$ & $\begin{array}{l}Z_{1} R \\
(\Omega / \\
\text { km) }\end{array}$ & $\begin{array}{l}Z_{1} X \\
(\Omega I \\
k m)\end{array}$ & $\begin{array}{l}\mathrm{Z}_{0} \mathrm{R} \\
(\Omega \text { I } \\
\mathrm{km})\end{array}$ & $\begin{array}{l}Z_{0} X \\
(\Omega I \\
\text { km) }\end{array}$ \\
\hline $\begin{array}{l}\text { MVTIC } 150 \\
\mathrm{~mm}^{2}\end{array}$ & 0,265 & 0,106 & 0.363 & 1.618 \\
\hline
\end{tabular}

Berdasarkan Tabel 1 dapat dihitung nilai impedansi $Z_{1}, Z_{2}$, dan $Z_{0}$ dari penyulang Gayatri

$$
\begin{aligned}
Z_{1} & =Z_{2} \\
& =(0,265+j 0,106) \Omega / \mathrm{km} \times 7,2 \mathrm{~km} \\
& =1,908+j 0,763 \Omega / \mathrm{km}
\end{aligned}
$$




$$
\begin{aligned}
Z_{0} & =(0,363+j 1,618) \Omega / \mathrm{km} \times 7,2 \mathrm{~km} \\
& =2,6136+j 11,6496 \Omega / \mathrm{km}
\end{aligned}
$$

Nilai jatuh tegangan dihitung berdasarkan titik gangguan yang diasumsikan dari titik $5 \%$ panjang penyulang sampai $100 \%$ panjang penyulang dengan kelipatan $5 \%$ tiap titik gangguan, sehingga didapat 20 titik gangguan jatuh tegangan. Hasil perhitungan untuk nilai jatuh tegangan pada titik gangguan $100 \%$ panjang penyulang dapat dihitung menggunakan Persamaan (2) sebagai berikut.

$$
\begin{aligned}
\Delta V & =I \times Z \\
& =I\left(R_{\cos \theta}+X_{\sin \theta}\right) \\
& =144((1,6218 \times 0,85)+(0,3815 \times 0,5)) \\
& =144 \times 2,0033 \\
& =288,4 \text { volt }
\end{aligned}
$$

\subsection{Menghitung Impedansi Sumber dan} Impedansi (Reaktansi) Trafo Tenaga

Perhitungan impedansi dapat dicari dengan mengetahui nilai MVA hubung singkat yang dihitung dengan Persamaan (3) sebagai berikut.

$$
\begin{aligned}
& M V A_{h s}=I_{h s 3 \theta \max }\left(\text { teg }_{\text {primer }} \text { trafo } x \sqrt{3}\right) \\
& =1,78 \mathrm{kA} \times(150 \mathrm{kV} \times \sqrt{3}) \\
& =461,5 \mathrm{MVA}
\end{aligned}
$$

Impedansi sumber dihitung mulai dari sisi primer $(150 \mathrm{kV})$ kemudian dihitung nilai impedansi impedansi sumber pada sisi sekunder (20 kV), Persamaan (4) dan (5) digunakan untuk menghitung nilai impedansi sumber sebagai berikut.

$$
\begin{aligned}
X s_{(150 \mathrm{kV})} & =\frac{k V^{2}}{M V A_{h s}} \\
& =\frac{150^{2}}{461,5} \\
& =48,75 \Omega \\
X s_{(20 \mathrm{kV})} & =\frac{20^{2}}{150^{2}} \times 48,75 \\
& =0,86 \Omega
\end{aligned}
$$

Nilai impedansi (reaktansi) trafo urutan positif dan negatif $\left(X_{T 1}=X_{T 2}\right)$ dapat dihitung menggunakan Persamaan (7) sebagai berikut.

$$
X_{T 1}=X_{T 2}=12,5 \% \times 6,67 \Omega=0,833 \Omega
$$

\subsection{Arus Hubung Singkat 3 Phasa, 2 Phasa, dan 1 Phasa ke Tanah \\ Nilai impedansi sumber dan impedansi} trafo yang telah dihitung sebelumnya kemudian digunakan untuk menghitung nilai impedansi ekivalen urutan positif, impedansi ekivalen urutan negatif dan juga impedansi ekivalen urutan nol dengan menggunakan Persamaan (8) dan (9), sehingga dari nilai impedansi ekivalen urutan positif, impedansi urutan negatif dan impedansi urutan nol dapat dihitung arus hubung singkat gangguan 3 phasa, 2 phasa, dan 1 phasa ketanah menggunakan Persamaan (10) - (12), seperti yang ditampilkan pada Tabel 2 .

Tabel 2. Nilai Arus Hubung Singkat

\begin{tabular}{|c|c|c|c|}
\hline $\begin{array}{c}\% \\
\text { Penyulang }\end{array}$ & If3 (A) & If2 (A) & If1 (A) \\
\hline 0 & 8786,6 & 5906,6 & 287,3 \\
\hline 5 & 6660 & 5767,7 & 286,5 \\
\hline 10 & 6488,6 & 5619,3 & 285,7 \\
\hline 15 & 6309,9 & 5464,5 & 284,9 \\
\hline 20 & 6126,9 & 5306 & 284,1 \\
\hline 25 & 5942,2 & 5146,1 & 283,3 \\
\hline 30 & 5758,1 & 4986,7 & 282,6 \\
\hline 35 & 5576,4 & 4829,3 & 281,8 \\
\hline 40 & 5398,3 & 4675,1 & 281 \\
\hline 45 & 5224,9 & 4524,9 & 280,3 \\
\hline 50 & 5057 & 4379,5 & 279,5 \\
\hline 55 & 4895 & 4239,2 & 278,8 \\
\hline 60 & 4739,1 & 4104,2 & 278 \\
\hline 65 & 4589,7 & 3974,7 & 277,3 \\
\hline 70 & 4446,4 & 3850,7 & 276,5 \\
\hline 75 & 4309,5 & 3732,1 & 275,8 \\
\hline 80 & 4178,7 & 3618 & 275,1 \\
\hline 85 & 4053,9 & 3510 & 274,3 \\
\hline 90 & 3934,8 & 3407 & 273,6 \\
\hline 95 & 3821,1 & 3309,2 & 272,9 \\
\hline 100 & 3712,8 & 3215,3 & 272,2 \\
\hline & & & \\
\hline
\end{tabular}

\subsection{Menghitung Nilai TMS dan Nilai TD} Tiap Gangguan Hubung Singkat

Jenis rele yang digunakan pada penyulang Gayatri adalah rele invers untuk rele jenis invers biasa diset dengan nilai $1,05-1,1$. Perhitungan nilai TMS untuk gangguan hubung singkat 3 phasa, 2 phasa, dan 1 phasa ke tanah menggunakan persamaan (14) adalah :

$$
\begin{aligned}
T M S_{i f 3 \theta} & =0,3 \times \frac{\left(\left(\frac{8786,6}{1818,6}\right)^{0,02}-1\right)}{0,14} \\
& =0,068 S I \\
T M S_{i f 2 \theta} & =0,3 \times \frac{\left(\left(\frac{5906,6}{1818,6}\right)^{0,02}-1\right)}{0,14} \\
& =0,051 S I
\end{aligned}
$$




$$
\begin{aligned}
T M S_{i f 1 \theta} & =0,3 x \frac{\left(\left(\frac{287,3}{1818,6}\right)^{0,02}-1\right)}{0,14} \\
& =0,014 S I
\end{aligned}
$$

Nilai TMS dari masing-masing gangguan hubung singkat, yaitu hubung singkat 3 phasa, 2 phasa, dan 1 phasa ke tanah yang telah dihitung sebelumnya, dapat digunakan untuk menghitung nilai Time Delay (TD) atau nilai waktu tunda kerja rele. Nilai $T D$ dari masing-masing gangguan hubung singkat dapat dilihat pada Tabel 3.

Tabel 3. Nilai Waktu Tunda Kerja Rele

\begin{tabular}{|c|c|c|c|}
\hline $\begin{array}{c}\% \\
\text { Penyulang }\end{array}$ & $\begin{array}{c}\text { (td) If3 } \\
\text { (detik) }\end{array}$ & $\begin{array}{c}\text { (td) If2 } \\
\text { (detik) }\end{array}$ & $\begin{array}{c}\text { (td) If1 } \\
\text { (detik) }\end{array}$ \\
\hline 5 & 0,36 & 0,30 & 0,300 \\
\hline 10 & 0,37 & 0,31 & 0,300 \\
\hline 15 & 0,38 & 0,32 & 0,301 \\
\hline 20 & 0,39 & 0,33 & 0,301 \\
\hline 25 & 0,40 & 0,34 & 0,301 \\
\hline 30 & 0,41 & 0,35 & 0,302 \\
\hline 35 & 0,42 & 0,36 & 0,302 \\
\hline 40 & 0,43 & 0,37 & 0,302 \\
\hline 45 & 0,45 & 0,38 & 0,303 \\
\hline 50 & 0,46 & 0,40 & 0,303 \\
\hline 55 & 0,48 & 0,41 & 0,303 \\
\hline 60 & 0,49 & 0,43 & 0,304 \\
\hline 65 & 0,51 & 0,45 & 0,304 \\
\hline 70 & 0,53 & 0,47 & 0,304 \\
\hline 75 & 0,55 & 0,49 & 0,305 \\
\hline 80 & 0,57 & 0,51 & 0,305 \\
\hline 85 & 0,59 & 0,54 & 0,306 \\
\hline 90 & 0,61 & 0,56 & 0,306 \\
\hline 95 & 0,64 & 0,59 & 0,306 \\
\hline 100 & 0,66 & 0,62 & 0,307 \\
\hline & & &
\end{tabular}

\subsection{Pengolahan dan Pengujian Data} Pada ANN

Langkah-langkah dalam pengolahan dan pengujian data menggunakan neural network adalah sebagai berikut.

a. Membuat variabel data yang berjumlah 80 data, terdiri dari data input dan output, yang masing-masing berjumlah 40 data.

b. Memisahkan data latih dan data uji, dari keseluruhan data kemudian dibagi menjadi dua bagian sama rata untuk data latih dan data uji, namun pada saat pengujian digunakan dua data, yaitu data latih dan data uji.

c. Penormalisasian data, ANN tidak dapat langsung mengenali data input, karena $A N N$ mengenali data dari polapola tertentu saja, oleh karena itu dilakukan penormalisasian data yang sesuai dengan $A N N$. d. Memasukkan dan menentukan parameter pengujian. Parameter yang digunakan antara lain, hidden layer yang berjumlah 40, kecepatan pembelajaran 0,3 dan jumlah maksimum iterasi adalah 60000 epoch. Berikut merupakan bentuk syntax neural network yang digunakan.

net=newff (INPUT, [40 4],\{'logsig' 'logsig'\}, 'traingd')

net.trainParam.epoch $=60000 ; 1$

net.trainParam.goal $=0.00001$;

net.trainParam.Ir = 0.3;

net $=\operatorname{train}($ net, $p, t)$;

Gambar 4 menunjukkan proses dan hasil pelatihan data menggunakan $A N N$.
Gambar 4. Neural Network Training Tool

Gambar 4 menunjukkan nilai iterasi, target, dan waktu yang digunakan selama pelatihan. Proses pelatihan berhenti pada nilai iterasi maksimumnya, dalam waktu 5 menit dan 36 detik, menghasilkan nilai target 0,000093, nilai ini merupakan nilai yang paling mendekati dari nilai target yang diharapkan.

Hasil pengujian dapat dibandingkan dengan data yang dimasukkan, dan dapat dihitung nilai Mean Squared Error (MSE) atau nilai selisih kesalahan. Hasil dari pengujian MSE dibagi menjadi dua karena pengujian dilakukan dengan menggunakan dua data yang telah dibagi, yaitu data hasil dengan urutan ganjil yang didapat dari pengujian menggunakan data latih dan 
data hasil dengan urutan genap yang didapat dari pengujian menggunakan data uji. Nilai MSE dari masing-masing output dapat dilihat pada Tabel 4.

Tabel 4 Nilai MSE Masing-Masing Output

\begin{tabular}{|c|c|c|}
\hline $\begin{array}{c}\text { MSE jatuh } \\
\text { tegangan }\end{array}$ & Pengujian Data Latih & 30,442319800 \\
\cline { 2 - 3 } & Pengujian Data Uji & 45,573926780 \\
\hline \multirow{2}{*}{ MSE If3 } & Pengujian Data Latih & 0,000331929 \\
\cline { 2 - 3 } & Pengujian Data Uji & 0,000378819 \\
\hline \multirow{2}{*}{ MSE If2 } & Pengujian Data Latih & 0,000481790 \\
\cline { 2 - 3 } & Pengujian Data Uji & 0,000491862 \\
\hline \multirow{2}{*}{ MSE If1 } & Pengujian Data Latih & 0,000321126 \\
\cline { 2 - 3 } & Pengujian Data Uji & 0,000407001 \\
\hline
\end{tabular}

Nilai awal kestabilan MSE dapat dilihat pada Gambar 5.
Gambar 5. Grafik Pelatihan ANN

Gambar 5 menunjukkan grafik pelatihan $A N N$ dimana nilai awal kestabilan MSE yang dicapai adalah 0,0000927. Hasil pengujian ini sudah mendekati nilai target yang telah ditentukan sebesar 0,00001 dengan pemilihan-pemilihan parameterparameter yang tepat, ditunjukkan pula pada grafik nilai MSE ini dicapai pada iterasi maksimum, yaitu iterasi 60000 yang telah diatur pada syntax.

\section{KESIMPULAN}

Simpulan analisis kecepatan kerja SACO menggunakan ANN menunjukkan nilai jatuh tegangan terbesar ada pada titik $100 \%$ (ujung) panjang penyulang yaitu sebesar 288,4 volt, pada proses pengujian menggunakan $A N N$ didapatkan nilai jatuh tegangan pada titik $100 \%$ (ujung) penyulang sebesar 274,7 volt. Nilai $M S E$ dari data latih dan data uji masing-masing adalah 30,4 dan 45,5 . Nilai jatuh tegangan ini tidak melebihi dari nilai $0,5 \mathrm{kV}$ nominal tegangan kerjanya. Waktu tunda (td) kecepatan kerja rele dari hasil perhitungan berbeda-beda sesuai jenis gangguan hubung singkat, waktu tunda tercepat ada di $5 \%$ panjang penyulang yaitu sebesar 0,3 detik di ketiga jenis gangguan hubung singkat, waktu tunda kerja semakin lama sampai diujung titik 100\% (ujung) panjang penyulang dengan kecepatan 0,6 detik pada gangguan hubung singkat 3 phasa dan 2 phasa. Pengujian terbaik didapatkan dengan hasil MSE 0,00032 menggunakan data latih pada gangguan hubung singkat 1 phasa ke tanah.

\section{DAFTAR PUSTAKA}

[1] D. Suswanto, Sistem Distribusi Listrik, Pertama. Padang: Universitas Negeri Padang, 2009.

[2] Abrar Tanjung, "Rekonfigurasi Sistem Distribusi 20 KV Gardu Induk Teluk Lembu dan PLTMG Langgam Power Untuk Mengurangi Rugi Daya dan Drop Tegangan," J. Sains Teknol. Dan Ind., vol. 11, no. 2, p. 7, Jun. 2014.

[3] Roger C. Dugan, Mark F, McGranaghan, Surya Santoso, and $\mathrm{H}$. Wayne Beaty, Electric Power System Quality, 2nd ed. India: McGraw-Hill Education, 2002.

[4] M. Suartika and I. W. Arta Wijaya, "REKONFIGURASI JARINGAN TEGANGAN RENDAH (JTR) UNTUK MEMPERBAIKI DROP TEGANGAN DI DAERAH BANJAR TULANGNYUH KLUNGKUNG," Maj. IIm. Teknol. Elektro, vol. 9, no. 2, Nov. 2012.

[5] Djoko Prasetyo, "Direktori Karya Inovasi PLN LITBANG.” PLN LITBANG Jakarta, Desember-2005.

[6] S. Haykin, Neural Networks: A Comprehensive Foundation, 2nd ed. Upper Saddle River, NJ, USA: Prentice Hall PTR, 1998.

[7] S. Kusumadewi, Membangun jaringan syaraf tiruan (menggunakan matlab \& excel link). Yogyakarta: Graha IImu, 2004.

[8] I. G. D. Arjana, "IDENTIFIKASI PENURUNAN KWALITAS DAYA PADA PENYULANG MENGGUNAKAN KOMBINASI TRANSFORMASI WAVELET DAN NEURAL NETWORK," Maj. IIm. Teknol. Elektro, vol. 6, no. 2, Sep. 2007. 